\title{
THE IMPACT OF MICRO-RESIDUE STUDIES ON SOUTH AFRICAN MIDDLE STONE AGE RESEARCH
}

\author{
Marlize Lombard' ${ }^{1}$ and Lyn Wadley \\ 1. Institute for Human Evolution \\ University of the Witwatersrand \\ WITS 2050 South Africa \\ Email: Marlize.Lombard@wits.ac.za \\ 2. Archaeology Department \\ School of Geography, Archaeology and Environmental Studies \\ University of the Witwatersrand \\ WITS 2050 South Africa
}

\begin{abstract}
The Middle Stone Age of South Africa currently plays a central role in studies of the origins of symbolic behaviour. Micro-residue analyses on stone tools from sites with long Middle Stone Age sequences and good organic preservation are producing direct contextual evidence and detailed information about past technologies and associated behaviours. In this chapter we provide a brief and selected overview of some of our published contributions and demonstrate how microresidue studies can now be used to assess hypotheses regarding hunting efficiency and hafting technologies. Compelling evidence is being produced that is contrary to the once-held notion that the Middle Stone Age shows little meaningful change through time. The cumulative results provide clear evidence for variability and change associated with anatomically modern humans. While our published work demonstrates our commitment to a multi-analytical approach to usetrace analysis, including micro-residue, use-wear and macrofracture analyses, we focus here on residues as it was also the focus of Tom Loy's research in South Africa.
\end{abstract}

\section{KEYWORDS}

Middle Stone Age, Howiesons Poort, Still Bay, Sibudu Cave, cognitive evolution, hunting technology, hafting technology

\section{INTRODUCTION}

There has been a marked increase in research interest in the African Middle Stone Age that spans the period of roughly $250 \mathrm{ka}$ to $25 \mathrm{ka}$ ago. The heightened awareness is due to new, multidisciplinary data stimulating debate on the origins of anatomically and behaviourally modern humans, and while the archaeological record is nowhere near complete, progress is being made. Exciting but hotly contested interpretations of African origins now rival earlier interpretations of a Eurasian origin for modern humans (e.g. Marean and Assefa 2005; but also see d'Errico 2003; d'Errico et al. 2003; Shea 2003). Genetic and fossil evidence suggest that, from the anatomical perspective, humans in Africa were nearly modern by about $160 \mathrm{ka}$ ago.

Fundamental questions are whether anatomical and cognitive modernity developed in tandem, and what criteria, if any, archaeologists should use to identify modern human behaviour 
(Henshilwood and d'Errico 2005; Henshilwood and Marean 2003, 2006; Kuhn and Hovers 2006; McBrearty and Brooks 2000; Shea 2003; Wadley 2001, 2006a). New results seem to suggest that symbolic behaviour in Africa extends far earlier than the $50 \mathrm{ka}$ 'Rubicon' (Henshilwood and Marean 2003; Marean and Assefa 2005; McBrearty and Brooks 2000; Mellars 1973, 1995, 2005, 2006; Minichillo 2005; Wadley 2006a, 2006b), and the Middle Stone Age of South Africa has claimed a central role in the quest for the origins of symbolic behaviour. It is against this background that the research of LW moved ever-deeper in time, first at Rose Cottage Cave in the Free State and more recently at Sibudu Cave in KwaZulu-Natal (Figure 1), and ML started exploring questions about Middle Stone Age hunting and hafting behaviour. These explorations and associated research questions and projects resulted in our approach to micro-residue analysis gaining its distinctive direction and momentum.

The first South African PhD in stone tool residue studies was completed in 2000 (Williamson 2000a) under the direction of Lyn Wadley and the late Tom Loy. This study introduced the basic principles and potential of residue analysis to Stone Age research on the sub-continent, where we have an approximately 2.5 million-year-old tool making tradition. From the start, our microresidue work was deeply embedded in archaeological questions that have arisen during the course of excavations at Rose Cottage Cave and Sibudu Cave (see Gibson et al. 2004; Lombard 2004, 2005; Wadley, Williamson and Lombard 2004; Williamson 1996, 1997, 2000b, 2004, 2005). Some of these questions centred on the use and hafting of Howiesons Poort backed tools, the role of ochre during the Middle Stone Age and changes in subsistence strategies. Building on this initial work, experimentation, modern replication and blind testing became integral parts of our research design, without losing sight of the main goal - to improve our understanding of human behaviour during the Middle Stone Age (Hodgskiss 2006; Lombard et al. 2004; Lombard and Wadley 2007a, b; Pargeter 2007; Rots and Williamson 2004; Wadley 2005a, 2005b, 2005c, 2006a; Wadley and Lombard 2007; Wadley, Lombard and Williamson 2004).

Both Rose Cottage Cave and Sibudu Cave have yielded hundreds of thousands of stone tools occurring in varying contexts over time, and we have systematically excavated and curated tools with residue studies in mind. At both sites, but particularly at Sibudu Cave, we have extraordinary evidence for environmental and cultural change (Wadley 2006b). It is important to us to take a holistic view and to position micro-residue analysis within the broader framework of data derived from fauna, botanical remains and site sediments (for recent multi-disciplinary contributions from Sibudu Cave see Wadley 2006b and references therein). The micro-residue work on stone tools is closely linked to our multi-disciplinary approach to research on the other archaeological material, and is intended to crosscheck and strengthen behavioural interpretations. It is against this background that we are also consistently attempting to improve our methodology and interpretative skills.

Rose Cottage Cave appears to have been occupied, perhaps intermittently, over a period of about 90,000 years (Pienaar 2006; Soriano et al. 2007; Valladas et al. 2005). Sibudu Cave has a long series of Middle Stone Age occupations with stone tool assemblages that can be attributed to a pre-Still Bay phase at the base of the sequence, a Still Bay Industry, a Howiesons Poort Industry, a post-Howiesons Poort phase, and late and final Middle Stone Age phases. A preliminary OSL age for the Still Bay is calculated at $\sim 73 \mathrm{ka}$, no ages for the Howiesons Poort are available yet, but a large suite of layers with post-Howiesons Poort assemblages has a weighted mean OSL age of $60.1 \pm 1.5 \mathrm{ka}$, the late Middle Stone Age phase has a suite of ages with a weighted mean average OSL age of $49.7 \pm 1.2 \mathrm{ka}$, and the final Middle Stone Age phase has an OSL age of about $37 \mathrm{ka}$ (Jacobs et al. submitted; Wadley and Jacobs 2006) (Figure 2). The Howiesons Poort Industry, which contains many backed tools such as segments, appears to shift seamlessly into the younger $\sim 60$ ka post-Howiesons Poort industry lacking backed tools (Wadley 2006b). Stratigraphically, the Howiesons Poort succeeds the Still Bay, but it is not yet known whether there is a hiatus between these two industries at Sibudu Cave (Wadley 2006b). 


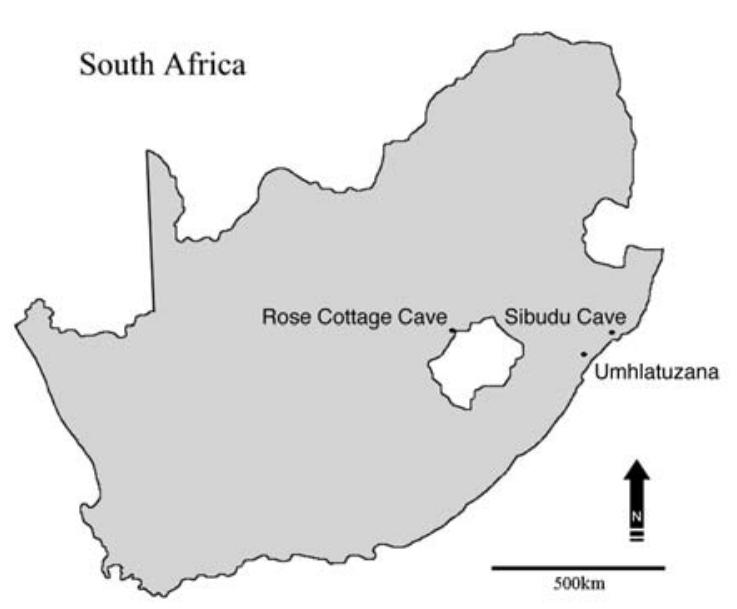

Figure 1: Map with deep-sequence KwaZuluNatal sites and Rose Cottage Cave.

\section{SELECTED METHODOLOGICAL DEVELOPMENTS}

In 2004 we published the protocols and results of our first two blind tests (Wadley, Lombard and Williamson 2004). The original aim was to assess ML's ability to identify a variety of plant and animal residues using light microscopy. However, issues and problems that arose during the testing process made it clear that greater value might be gained from the lessons that we learnt about methodology and the direction for future micro-residue research (for discussions see Lombard and Wadley 2007a, 2007b and Wadley and Lombard 2007). Addressing problems identified during our first tests stimulated research and subsequently two more tests were conducted, and this time they were totally fieldbased (Lombard and Wadley 2007a).

The series of tests helped to evaluate and improve the quality of data that could be gained through micro-residue analysis using light microscopy. For example it was shown that, based on their microscopic morphological appearance, animal residues could have been previously mistaken for plant residues (Figure 3). This discovery has far-reaching implications for the interpretation of archaeological assemblages, site functions and associated behavioural hypotheses. The same tests also demonstrated that the rock types used to produce stone tools might influence the quality of functional interpretations based on micro-residue analysis (for example, highly reflective quartz makes recognition of residues challenging, and the smooth surfaces of quartz do not readily retain residues).

We introduced a multi-stranded approach (Lombard and Wadley 2007a, 2007b; Wadley and Lombard 2007). This requires that functional and hafting interpretations are based not only on the presence of single identified micro-residues, but also on their association with related residues, their frequency, distribution patterns, layering, orientation, and the way in which they adhere to the tool. We believe that this approach, in combination with use-wear and macrofracture analyses (see Lombard 2005, 2006b, 2007a for application of this approach), controlled curatorial circumstances and the microscopic study of associated sediment samples and potential contaminants, provides a cautious, but secure strategy for the detailed interpretation of archaeological residues (Lombard and Wadley 2007a, 2007b; Wadley and Lombard 2007). ML also developed a method for creating quantifiable, comparable data for the interpretation of micro-residue distribution patterns (Lombard 2004, 2005, 2006a, 2007a, 2007b, in press). Using this method it is shown that, with adequate tool samples and good organic residue preservation, sufficient data can be generated to compare results from different assemblages or micro-stratigraphic archaeological contexts. The results can also be statistically tested for the possibility of coincidental distribution patterns (Lombard 2005, 2007 b). Interpretations based on such data have the potential to enhance considerably the resolution of our knowledge of human behaviour in the distant past.

\section{IMPLICATIONS FOR OUR CURRENT KNOWLEDGE OF HUNTING AND HAFTING BEHAVIOURS}

\section{A brief background}

Effective hunting with hafted weapons has long been part of the 'modernity' debate. Although evidence for active hunting or the presence of hafted stone tools was sometimes considered to imply modern behaviour (e.g. Ambrose 2001 and Klein 2000 and references in both), anatomically archaic humans also seem to have hafted tools and hunted (e.g. Rots and Van Peer 2006). This 


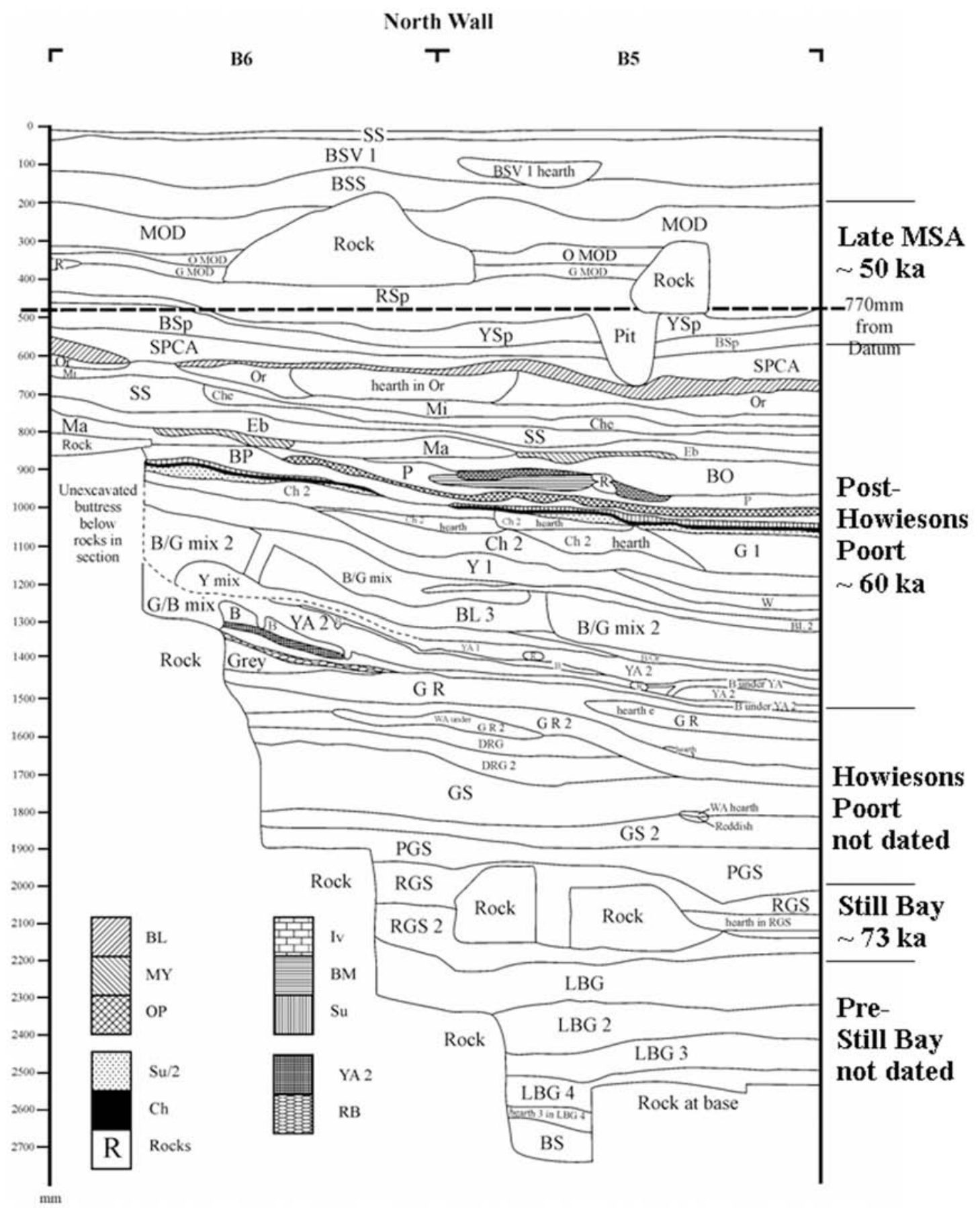

Figure 2: North wall stratigraphy at Sibudu Cave showing the main occupational phases and associated approximate ages. 

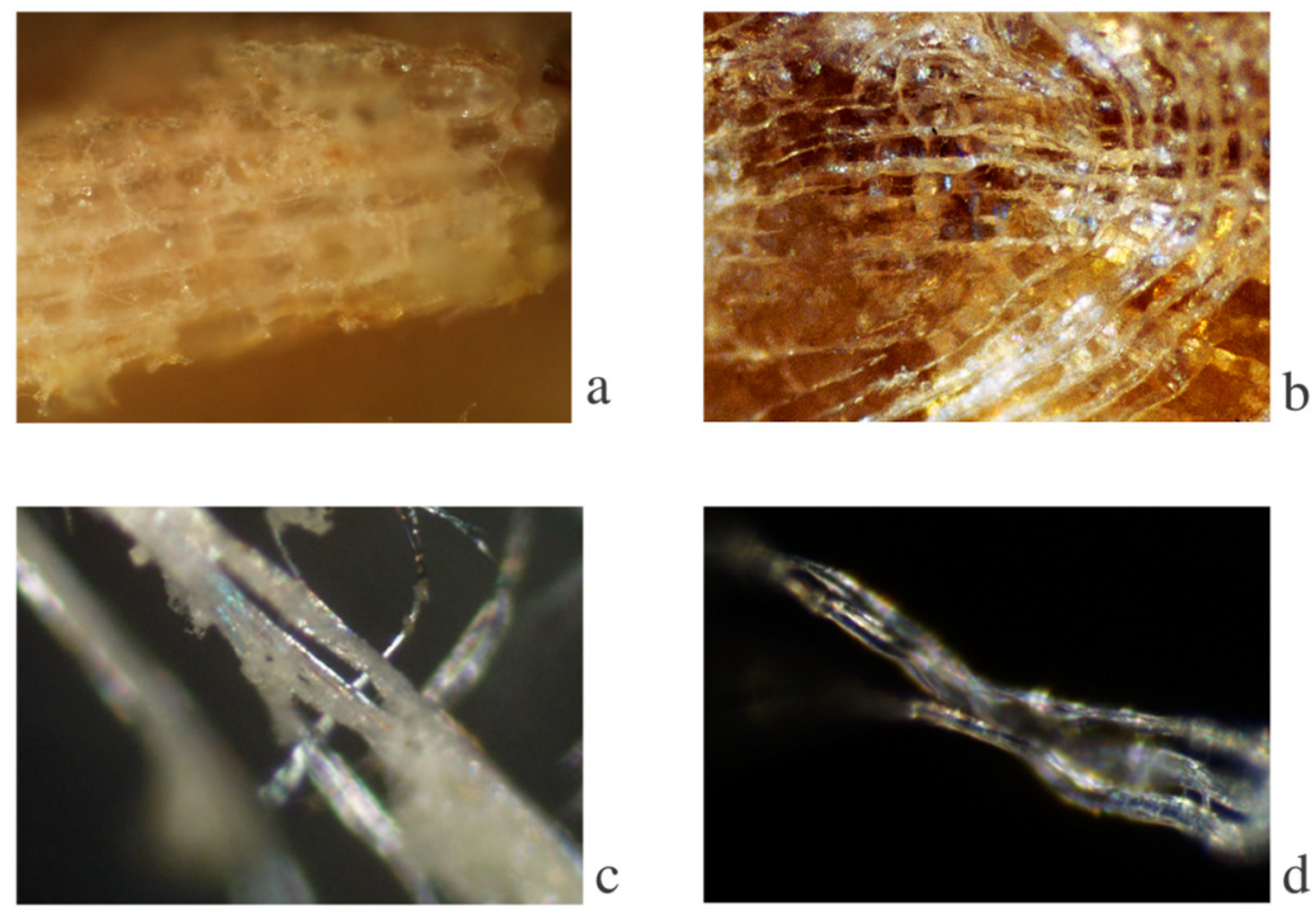

Figure 3: Selected images of replicated vegetal and faunal microresidues highlighting identification complications. (a) Inner epidermal cells of wet wood (Combretum zeheri) on a tool as a result of scraping bark, photographed at 200x. (b) Longitudinally orientated, striated muscle tissue on a tool as a result of cutting beef, photographed at 200x. (c) Plant fibres on the edge of a tool used to scrape fibrous leaf (Sanseviera pearsonii), photographed at 200x. (d) Collagen fibre on the edge of a replicated tool used to cut fatty cartilage of an Aepyceros melampus carcass, photographed at 200x. Figure originally published in Lombard and Wadley (2007a).

indicates a complex relationship between technological sophistication and behaviour that could be considered symbolic (and therefore modern). We know that symbolic behaviour can be traced with certainty to at least $82 \mathrm{ka}$ in North Africa (Bouzouggar et al. 2007) and to a similar age in southern Africa (e.g. Henshilwood et al. 2002, 2004) because of personal ornaments that have been found at Taforalt (Morocco) and Blombos (South Africa). Thus we focus on hunting and hafting behaviour during the MSA not to provide further evidence for symbolic behaviour, but to increase our knowledge of past technologies, highlighting the complex, variable and multifaceted nature of the archaeological record. Our brief overview of previously published results provides a summary of our contributions based on this approach. For more detailed and contextual discussions, please consult the primary publications.

\section{Selected results for the post-Howiesons Poort}

A multi-analytical functional study suggests that lithic points from the post-Howiesons Poort and late Middle Stone Age layers at Sibudu Cave, with ages between about $60 \mathrm{ka}$ and $50 \mathrm{ka}$ ago, were predominantly used as hafted spear tips. The quantification, plotting and chi-square statistical tests on the distribution patterns of 440 residue occurrences on 24 unbroken points show that the distribution of the residue types cannot be considered coincidental (Lombard 2004, 2005). The traces indicate the use of wooden shafts - revealing a hidden wood-working industry for which there is little additional evidence in the southern African Middle Stone Age (Figure 4). The stone points were probably glued to the shafts with an adhesive and then lashed with plant twine for added strength during use. 
The evidence indicates that the spears were most likely used as thrusting or throwing spears. This impression is supported by technological and morphometric data that fall within the expected range of thrusting or throwing spears (Shea 2006; Villa and Lenoir 2006; Villa and Lenoir in press; Villa et al. 2005). Further indicators for effective hunting during this phase at Sibudu Cave come from the associated faunal assemblage (Cain 2006; Plug 2004; Wells 2006). The age profiles of the Sibudu Cave samples show that there are not many bones from juvenile or very old animals: most animals are adults, with some sub-adults. Carnivore-damaged bone is scarce in relation to the size of the sample. These factors indicate that the people using the cave between 50 and 60 ka actively hunted rather than scavenged, and were regularly targeting large animals in their prime (Plug 2004; Wells 2006).

\section{Selected results for the Howiesons Poort}

Based on their small size and apparent standardisation, it has often been hypothesized that backed tools from the Howiesons Poort were hafted (H.J. Deacon 1989, 1993; J. Deacon 1995; Wurz 1999). Initial micro-residue evidence for the hafting of such tools from the Howiesons Poort at Rose Cottage Cave (between about 68 and 60 ka old), was provided by Gibson et al. (2004). The spatial distributions of ochre, plant tissue, plant fibres and white starchy residue on 48 backed tools were seen as indications for hafting. The data were interpreted to indicate that backed blades could have been hafted laterally, segments (the type fossil of the Howiesons Poort Industry and also called crescents or lunates) might have been placed transversely into their hafts, while obliquely backed blades were possibly hafted with their short axis in the haft (Gibson et al. 2004).

A more recent study of the micro-residues and other associated use-traces on all the unwashed Howiesons Poort segments from Sibudu Cave provides further resolution for hafting technologies during this industry (Lombard in press). Here it is shown that most segments were indeed hafted, but that it might be difficult to distinguish whether they were hafted transversely, longitudinally or as pairs to form a point. When cumulative use-trace data (micro-residues, usewear and macrofractures) are considered, however, it is shown that segments were probably hafted in a variety of positions and that there might have been differences in preferred hafting configurations during sequential phases of the Howiesons Poort at Sibudu Cave.

Interpretation of the micro-residues through the Howiesons Poort sequence also shows that there might have been time-related variability in haft materials; the oldest segments seem to have been hafted to bone and the youngest ones to wood, with a transitional phase where either bone or wood may have been used as shafts (Figure 5). These outcomes provide crucial evidence for relatively quick change and variability in technological behaviour during the Howiesons Poort, thereby contradicting the notion of slow change or even stasis during Middle Stone Age industries. Bone-hafting during the Howiesons Poort adds a new dimension to our understanding of hafting technologies and the composite tools of which segments were components (Lombard in press).

The micro-residues showed that segments were mostly used throughout the Howiesons Poort sequence to process animal material, and based on associated macrofracture and use-wear data, there are strong indications that they were predominantly used as inserts (tips, barbs or cutting inserts) for hunting tools (Lombard 2006b, in press) (Figure 6). Preliminary impressions of the Howiesons Poort faunal material indicate a wide range of species, with the little blue duiker well-represented (Clark and Plug submitted). Wadley (2006b) suggests that such tiny forest dwellers could have been trapped rather than hunted with spears or arrows. If we accept the interpretation for the principal hunting function of segments and Wadley's suggestion for the use of traps as reflecting real scenarios for meat procurement, it implies that people used highly variable and specialised hunting technologies more than $60 \mathrm{ka}$ ago.

\section{Selected results for the Still Bay}

Recently a study was conducted on a sample of Still Bay pointed tools from Sibudu Cave (older than $70 \mathrm{ka}$ ). The sample size is still small, so that assemblage-level studies similar to those conducted on the Howiesons Poort segments are not yet possible. However, a detailed tool-by- 

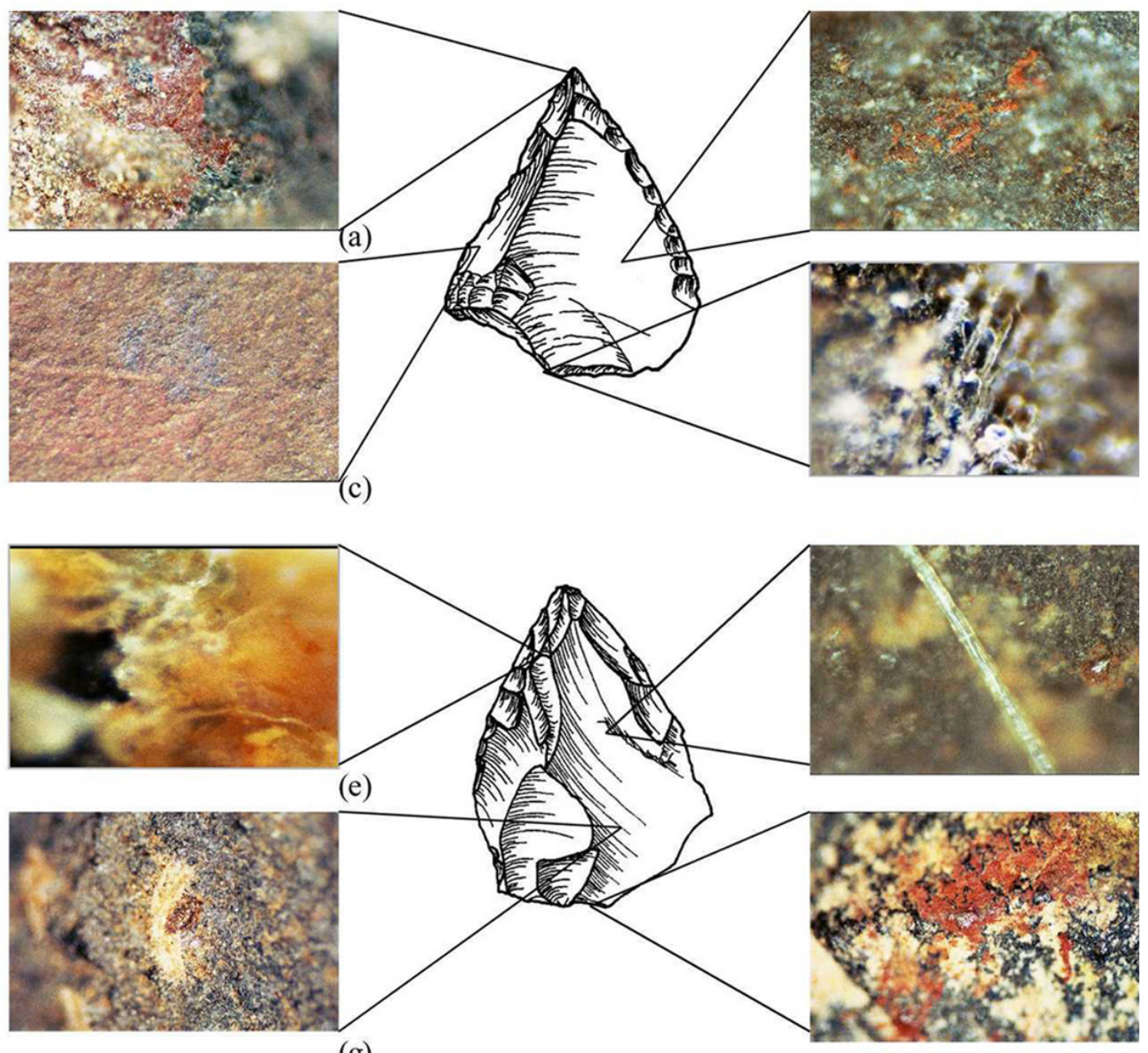

(g)

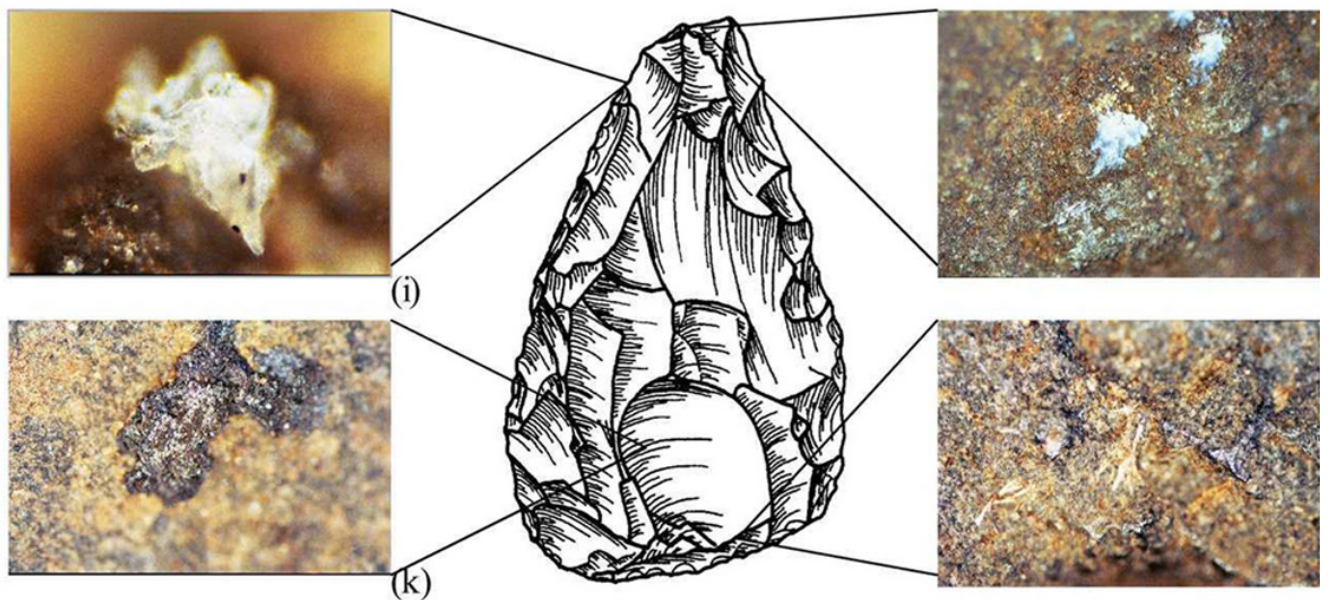

Figure 4: Selected tools and micrographs from the post-Howiesons Poort point sample, Sibudu Cave, indicating hunting and hafting. (a) A thick blood residue deposit, photographed at 200x. (b) A diagonally deposited ochre smear, photographed at 200x. (c) A transverse striation associated with ochre and plant exudate, photographed at 50x. (d) Bark cells or epidermal cell tissue, photographed at 500x. (e) Animal tissue, photographed at 500x. (f) Animal hair, photographed at 200x. (g) Woody residue trapped under a resin deposit, photographed at 100x. (h) A thick ochre and macerated wood deposit, associated with a diagonal striation and bright wood polish, photographed at 200x. (i) Bone and or sheet collagen, photographed at 500x. (j) Fatty residue, photographed at 100x. (k) Thick resinous deposit with wood cell imprint, photographed at 200x. (l) Woody fibres and resin associated with bright wood polish, photographed at 100x. Figure originally published in Lombard (2005). 

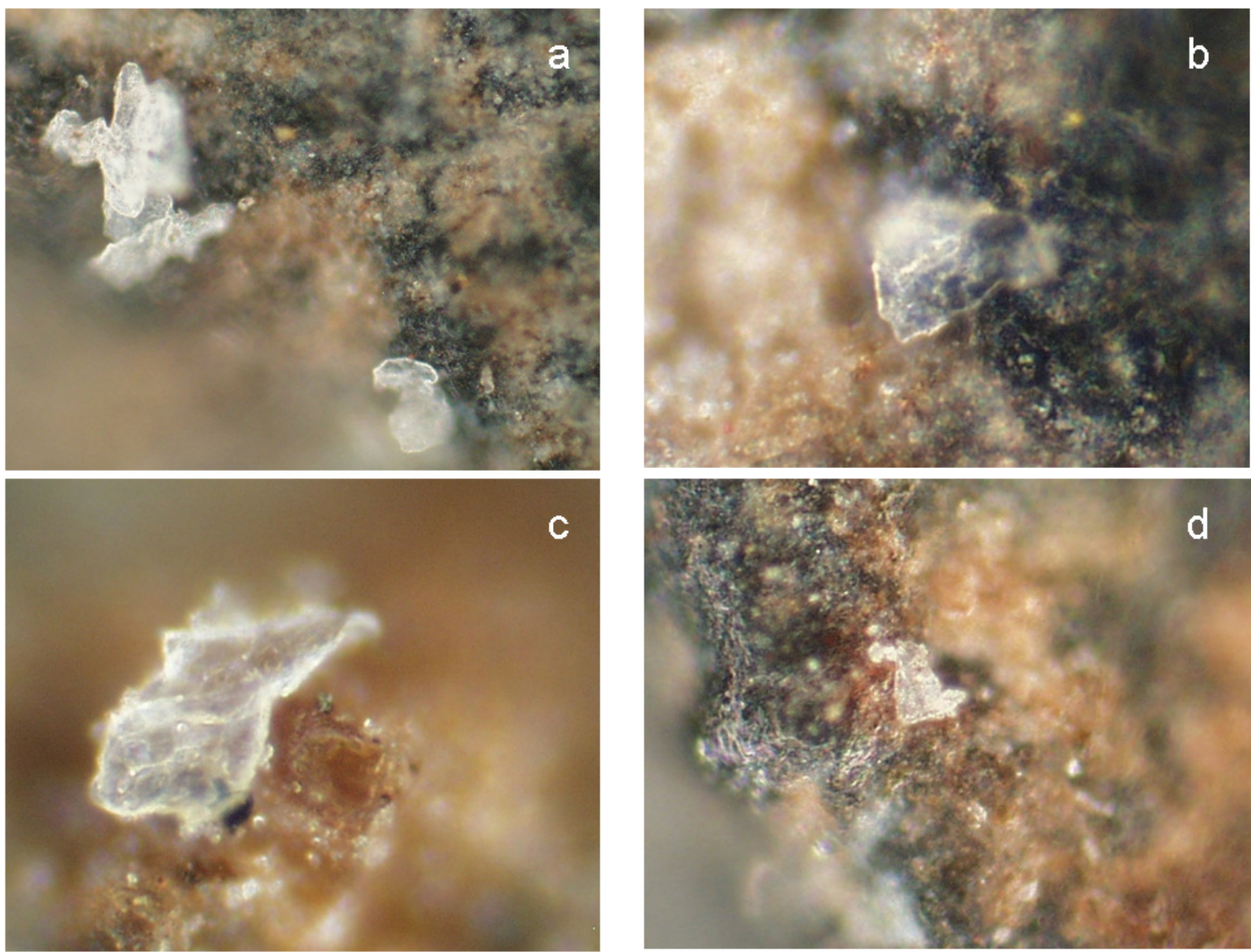

Figure 5: Bone residues superimposed on resinous residues on the backed portions of four different Howiesons Poort segments from Sibudu Cave; (a) photographed at 100x, (b) photographed at 200x, (c) photographed at 500x, (d) photographed at 200x. Figure originally published in Lombard (in press).

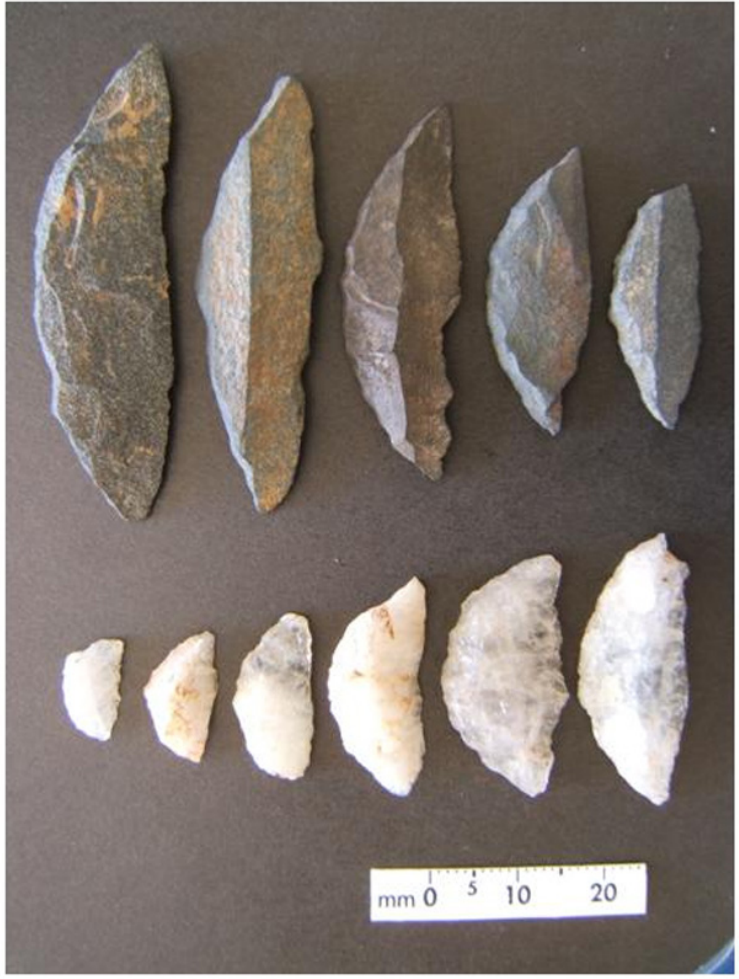

a

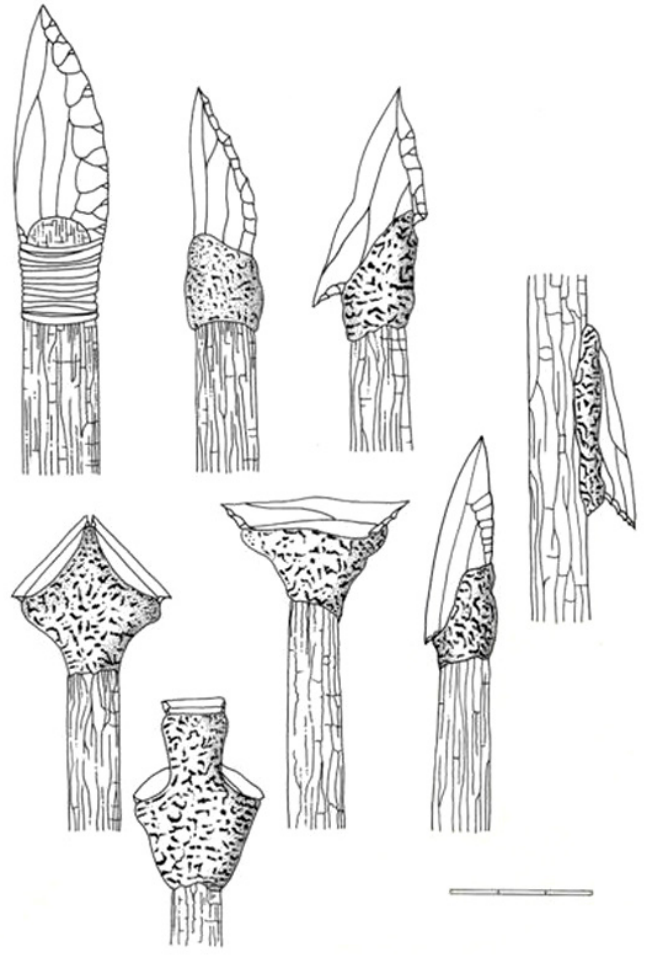

b

Figure 6: (a) Selected Howiesons Poort segments from the Umhlatuzana assemblage. (b) Potential hafting configurations re-drawn by L. Davis after Nuzhnyj (2002). 
tool analysis made it possible to test existing hypotheses and generate new working hypotheses for the functions and hafting technologies of these tools (Lombard 2006b). For example, Wadley (2006b) suggested that Sibudu's double-pointed, bifacial points with asymmetrical bases were not intended to be reversible in their hafts, but that the bases were pointed to facilitate a type of hafting that was favoured at the time. The micro-residue distribution patterns and other use-traces on the two unbroken points of this type support this suggestion (Figure 7). Furthermore, both tools show signs of having been used as knives for butchering activities. It is thus possible that the asymmetrically-pointed bases were an adaptation to facilitate the effective hafting of the tools as knives (see Lombard 2006b) (Figure 8). This also supports Minichillo's (2005) and Shea's (2006) suggestions that some Still Bay points from the Cape were used as knives.

There is one triangular bifacial point In the Sibudu sample that is similar in morphology to post-Howiesons Poort points. Macro-fractures and the distribution of animal residues on this point, and also on distal fragments of other points, show that they could have been used as hunting weapons. Thus, a current working hypothesis is that the asymmetrical points with pointed bases were hafted as knives, while symmetrical, triangular points were possibly hafted as hunting weapons. Continued work at Sibudu Cave and other sites with Still Bay assemblages will test this hypothesis. The preliminary results imply, however, that Middle Stone Age points from Still Bay contexts might have been used and hafted differently from points from the younger Middle Stone Age phases.

\section{The use of ochre during the Middle Stone Age}

Ochre has been intensely discussed in the literature because its presence is sometimes regarded as evidence for early symbolism (e.g. Ambrose 1998; Barham 1998, 2002; Barton 2005; Conard 2005; d'Errico 2003; Hovers et al. 2003; Watts 1998, 2002; Wreschner 1980, 1982). The large quantities of ochre retrieved from Middle Stone Age sites (Watts 2002) and the engraved ochre fragments from Blombos Cave with an age of about $77 \mathrm{ka}$ (Henshilwood et al. 2002) mean that the Middle Stone Age of South Africa is central to any debates about ochre. The research conducted on the tools from Sibudu Cave and Rose Cottage Cave and related experimental work has considerably augmented our understanding of the applications of pigmentatious materials such as iron hydroxides and iron oxides, casually referred to as ochre (see Gibson et al. 2004; Hodgskiss 2006; Lombard 2004, 2005; Wadley 2005a, 2005b, 2006a; Wadley, Williamson and Lombard 2004). For example, when micro-residue analysis was used to establish the relationship between resin and ochre on a sample of 53 Howiesons Poort segments from Sibudu Cave it was demonstrated that most of the ochre $(80 \%$, total $\mathrm{n}$ of occurrences $=502)$ and resin occurrences $(87 \%$, total $\mathrm{n}$ of occurrences $=585)$ are located on the backed portions (Lombard 2006a) (Figure 9). These portions of backed tools are generally associated with hafting based on ethnographic and archaeological examples from a variety of contexts (e.g. Becker and Wendorf 1993; Bocquentin and Bar-Yosef 2004; Clark 1977; Clark et al. 1974; Goodwin 1945; Phillipson 1976).

The results are interpreted as compelling, direct evidence that the tools were hafted, and that ground ochre was used in the adhesive recipe. It supports the hafting evidence for backed tools from the Howiesons Poort at Rose Cottage Cave and previous observations about the association of ochre with Middle Stone Age hafting technology (Gibson et al. 2004; Wadley, Williamson and Lombard 2004). A similar trend for the distribution of ochre and resin residues on the Sibudu segments was documented on a sample of 30 non-quartz Howiesons Poort segments from Umhlatuzana Rock Shelter, about 100 km south-west of Sibudu Cave in KwaZulu-Natal (Lombard 2007b). However, when a sample of 25 quartz segments from Umhlatuzana Rock Shelter was analysed using the same methodology, 269 resin occurrences and only 43 ochre occurrences were counted. Although both residues were concentrated on the backed edges, $68 \%$ of the quartz segments have resin but no ochre on them. The same is true for only $23 \%$ of the nonquartz sample from the shelter, and 9.5\% of the Sibudu Cave sample (Lombard 2007b).

The quartz and crystal quartz segments are not only generally smaller than those made on hornfels and dolerite, but they are also less elongated. Based on these morphological attributes 

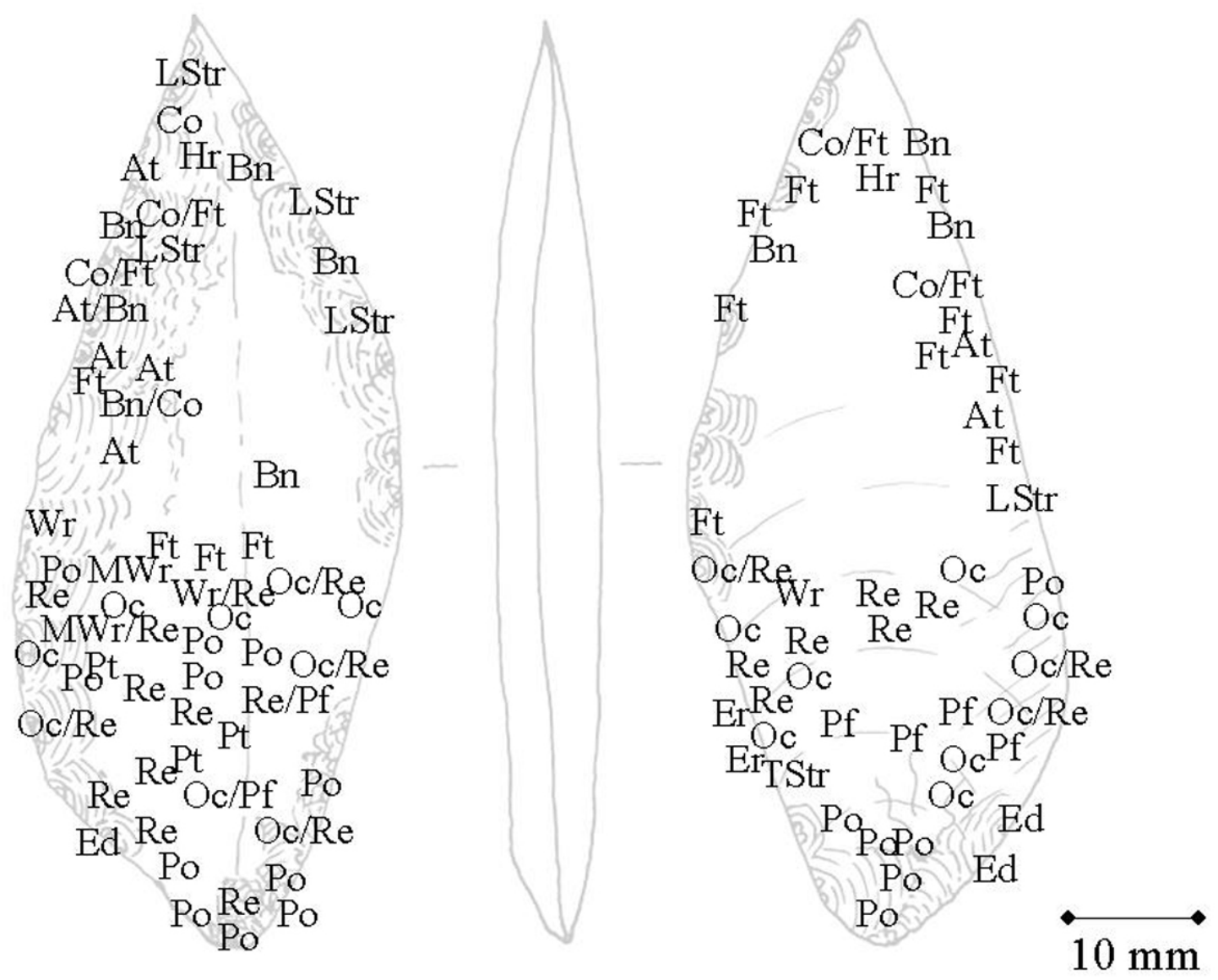

Figure 7: Example of the use-trace plots on a double-pointed, asymmetrical bifacial point from the Still Bay at Sibudu Cave. At $=$ animal tissue, $\mathrm{Bl}=$ blood, $\mathrm{Bn}=$ bone, $\mathrm{Bs}=$ brown stain, $\mathrm{Co}=$ collagen, $\mathrm{Ed}=$ edge damage, $\mathrm{Er}=$ edge rounding, $\mathrm{Ft}=$ animal fat, $\mathrm{Hr}=$ hair, $\mathrm{LStr}$ $=$ longitudinal striation, $\mathrm{MWr}=$ macerated woody residue, $\mathrm{Oc}=$ ochre, $\mathbf{P f}=$ plant fibre, $\mathrm{Po}$ $=$ polish, $\mathrm{Pt}=$ plant tissue, $\mathrm{Re}=$ resin, $\mathrm{TStr}=$ Transverse striations, $\mathrm{Wr}=$ woody residue. Figure originally published in Lombard (2006b).

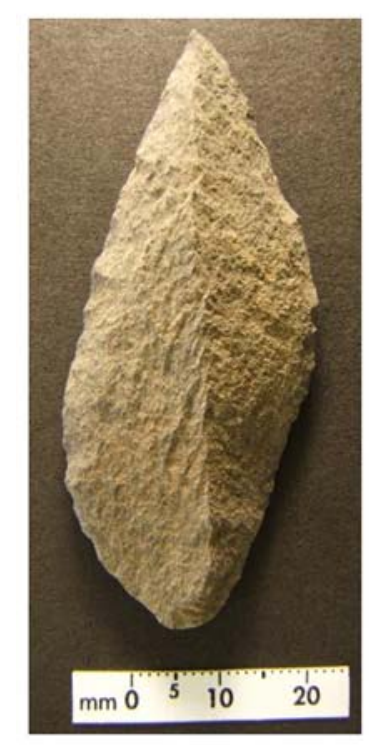

a

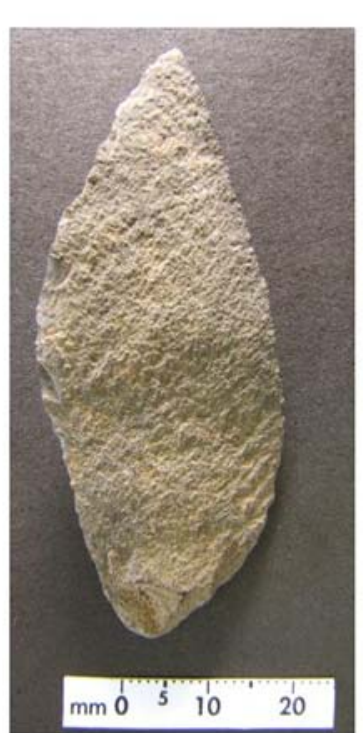

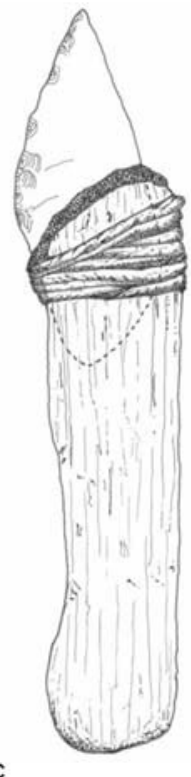

Figure 8: Hypothetical reconstruction of a double pointed, asymmetrical bifacial Still Bay point as a butchering knife with a wooden haft based on use-trace analysis. Drawing by $P$. Letley. 

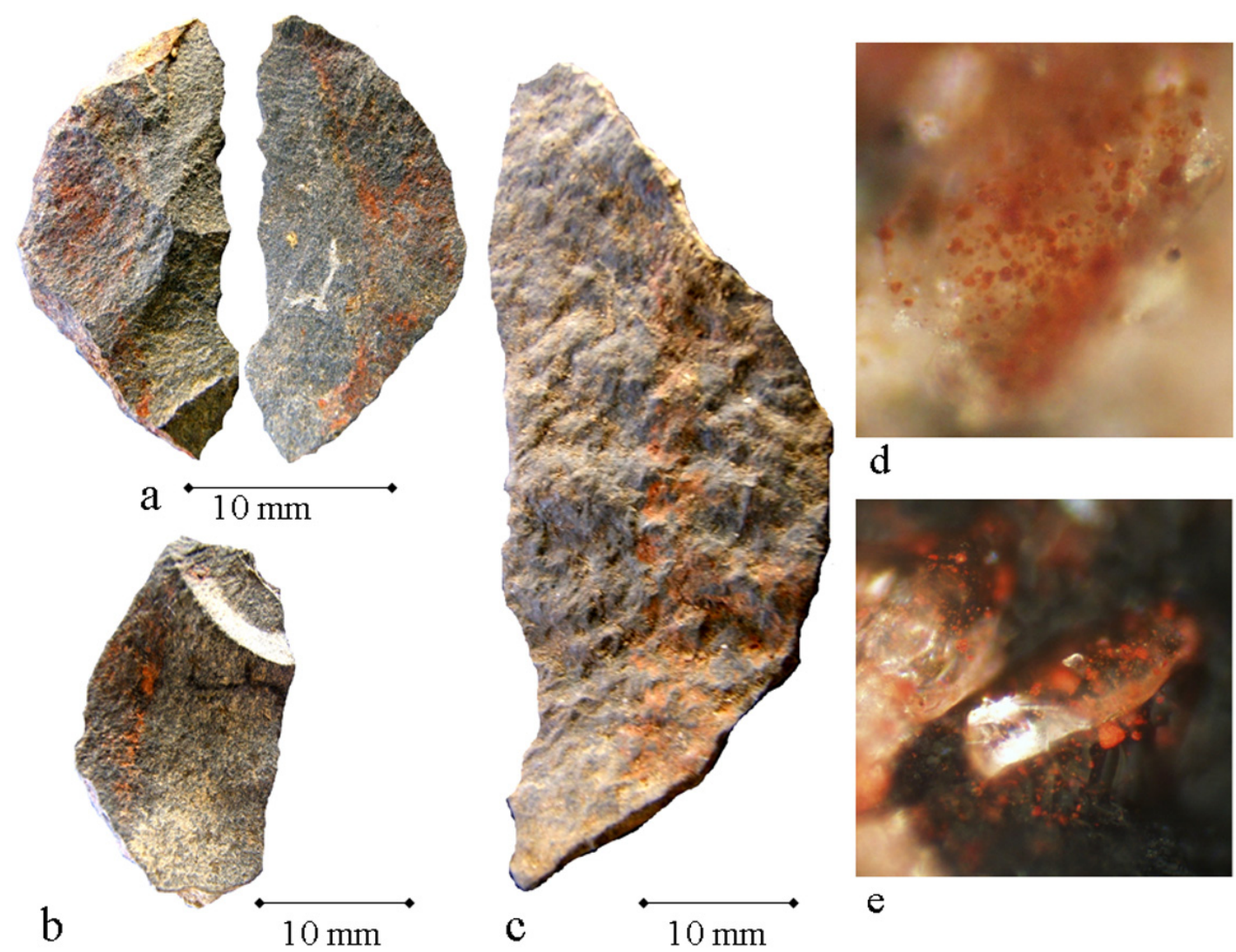

Figure 9: (a-c) Howiesons Poort segments from Sibudu Cave with macroscopically visible ochre residues on their backed portions. (d) Ochre grains in a clear resin deposit recorded on the backed portion of a Howiesons Poort segment from Sibudu Cave, photographed at 200x. (e) Ochre grains in a clear resin deposit on a replicated stone tool that was hafted to a wooden haft with an ochre-loaded adhesive.

we have suggested that they could have been hafted differently from the larger, longer segments produced on other raw materials (Delagnes et al. 2006). Quartz is also very hard (Moh's scale 7; Bishop et al. 2001) and the surface is smooth and glass-like. During replication and blind testing (Lombard and Wadley 2007a) it was found that residues do not adhere to the hard, smooth surfaces of quartz to the same degree as they seem to adhere to more porous, coarser-grained raw materials. It is therefore feasible to consider that a different, possibly more 'sticky', adhesive recipe may have been used for the hafting of quartz tools. Our ochre research reported here and elsewhere does not necessarily conflict with interpretations of Middle Stone Age ochre-use as symbolic. Instead, our findings imply that at least from about $70 \mathrm{ka}$ ago, and probably before, people had sophisticated knowledge of the properties of ochre, which made it a suitable aggregate for use in strong glues. Our findings enrich understanding of past technologies, which were by no means primitive.

\section{CONCLUSION}

The aim of this paper is to illustrate how stone tool micro-residue analysis in South Africa has evolved in close correlation with Middle Stone Age excavations, experimental research projects and international research trends. The methodology and reference collections, which were developed during replication for experimental projects and blind tests, enable us to generate quantitative data. Such data can be used for comparison with archaeologically recovered assemblages from various contexts at the same site, or even assemblages from different sites. One example is the 
comparison of the ochre and resin distribution patterns on quartz and non-quartz Howiesons Poort segments from two KwaZulu-Natal sites (Lombard 2007b).

Both the Howiesons Poort and Still Bay technocomplexes are central to the debate about the emergence of modern cognitive behaviour (Ambrose 2006; H.J. Deacon 1989, 1995, 2001; Deacon and Wurz 1996; Henshilwood et al. 2001a, 2001b; Lombard 2007a; Minichillo 2005; Wadley 2007; Wurz 1999; Wurz and Lombard in press). Micro-residue analyses conducted within the context of these bigger focus areas are starting to provide detailed, empirical evidence for hunting and butchery activities as well as insight into the complexities of hafting technologies practised during the Middle Stone Age.

Micro-residue analyses provide evidence to support other data that imply effective and innovative hunting (e.g. Marean and Assefa 1999). The results of these focused research projects inform on ancient technological skills and planning abilities. More than $70 \mathrm{ka}$ ago, people understood the properties of various raw materials and tool shapes, sizes and weights, and they seem to have adapted their hunting, butchery and adhesive technologies accordingly. We have generated evidence for change and variability during the Middle Stone Age that might indicate cumulative advances in cognition from at least $70 \mathrm{ka}$ ago. If we accept that people in South Africa behaved symbolically before $70 \mathrm{ka}$ ago (e.g. Henshilwood and d'Errico 2005), we ought to expect that the evidence for change and complexity in behaviours will become increasingly evident in the archaeological record after about $70 \mathrm{ka}$.

It is understood here that the mere existence of, or evidence for, changes in technologies such as hunting weapons or hafting strategies do not provide evidence for or against symbolic behaviour. The discernible technological variability in the Middle Stone Age record helps, however, to dispel previous notions of simple, unchanging technologies and subsistence patterns. The closer that we get to understanding everyday life in the remote past, represented in tasks such as hunting and hafting, the more it seems that these ancient hunter-gatherers may have behaved similarly to their more recent counterparts.

\section{ACKNOWLEDGEMENTS}

We thank the Editorial Committee for the invitation to contribute to this volume and express our gratitude to the late Tom Loy who introduced residue studies to researchers in South Africa. We are indebted to all students and colleagues who partook in the Rose Cottage Cave and Sibudu Cave excavations or contributed to ACACIA (Ancient Cognition and Culture in Africa) research projects. Our appreciation also goes to the Department of Archaeology at the University of the Witwatersrand for the use of their microscope and digital micrograph equipment. The research of Marlize Lombard is funded by PAST (Palaeontological Scientific Trust) and supported by the Natal Museum. Lyn Wadley received funds from the National Research Foundation of South Africa and is supported by the University of the Witwatersrand. The opinions expressed here, or any oversights, are those of the authors and are not necessarily to be attributed to the funding agencies or supporting organisations.

\section{REFERENCES}

Ambrose, S. H. 1998. Chronology of the Later Stone Age and food production in East Africa. Journal of Archaeological Science 25:179-184.

Ambrose, S.H. 2001. Palaeolithic technology and human evolution. Science 291:1789-1753.

Ambrose, S.H. 2006. Howiesons Poort lithic raw material procurement patterns and the evolution of modern human behaviour. Journal of Human Evolution 50:356-369.

Barham, L. 1998. Possible early pigment use in south-central Africa. Current Anthropology 39:703-710. 
Barham, L. 2002. Systematic pigment use in the Middle Pleistocene of south-central Africa. Current Anthropology 43: 181-190.

Barton, L. 2005. Origins of culture: functional and symbolic uses of ochre. Current Anthropology 46:499.

Becker, M. and F. Wendorf 1993. A microwear study of a Late Pleistocene Quadan assemblage from southern Egypt. Journal of Field Archaeology 20:389-398.

Bishop, A.C., A.R. Woolley, and W.R. Hamilton 2001. Minerals, Rocks and Fossils. London: George Philip's.

Bocquentin, F. and O. Bar-Yosef 2004. Early Natufian remains: evidence for physical conflict from Mt. Carmel, Israel. Journal of Human Evolution 47:19-23.

Bouzouggar, A., N. Barton, M. Vanhaeren, F. d'Errico, S. Collcutt, T. Higham, E. Hodge, S. Parfitt, E. Rhodes, J-L Schwenniger, C. Stringer, E. Turner, S. Ward, A Moutmir and A. Stambouli 2007. 82,000-year-old shell beads from North Africa and implications for the origins of modern human behaviour. PNAS 104:9964-9969.

Cain, C.R. 2006. Human activity suggested by the taphonomy of 60 ka and 50 ka faunal remains from Sibudu Cave. Southern African Humanities 18(1):241-260.

Clark, J.D. 1977. Interpretations of prehistoric technology from ancient Egyptian and other sources. Part II: prehistoric arrow forms in Africa as shown by surviving examples of the traditional arrows of the San Bushmen. Paléorient 3:127-150.

Clark, J.D., J.L. Phillips and P.S. Staley. 1974. Interpretations of prehistoric technology from ancient Egyptian and other sources. Part 1: ancient Egyptian arrows and their relevance for African prehistory. Paléorient 2:323-388.

Clark, J.L. and I. Plug submitted. Animal exploitation strategies during the South African Middle Stone Age: Howiesons Poort and post-Howiesons Poort fauna from Sibudu Cave.

Conard, N.J. 2005. An overview of the patterns of behavioural change in Africa and Eurasia during the Middle and Late Pleistocene. In F. d'Errico and L. Backwell (eds) From Tools to Symbols: From Early Hominids to Modern Humans, pp. 295-332. Johannesburg: Witwatersrand University Press.

Deacon, H.J. 1989. Late Pleistocene palaeoecology and archaeology in the southern Cape, South Africa. In P. Mellars and C.B. Stringer (eds) The Human Revolution: Behavioural and Biological Perspectives of the Origins of Modern Humans, pp. 547-564. Edinburgh: Edinburgh University Press.

Deacon, H.J. 1993. Southern Africa and modern human origins. In M.J. Aitken, C,B. Stringer and P. Mellars (eds) The Origins of Modern Humans and Impact of Chronometric Dating, pp. 104-117. Princeton: Princeton University Press.

Deacon, H.J. 1995. Two late Pleistocene-Holocene depositaries from the Southern Cape, South Africa. South African Archaeological Bulletin 50:121-131.

Deacon, H.J. 2001. Modern human emergence: an African archaeological perspective. In P.V. Tobias, M.A. Raath, J. Moggi-Cecci and G.A. Doyle (eds) Humanity from African Naissance to Coming Millennia, pp. 213-222. Johannesburg: University of the Witwatersrand Press. 
Deacon, H.J. and S. Wurz 1996. Klasies River Main Site, Cave 2: a Howiesons Poort occurrence. In G. Pwiti and R. Soper (eds) Aspects of African Archaeology, pp. 213-218. Harare: University of Zimbabwe Publications.

Deacon, J. 1995. An unsolved mystery at the Howieson's Poort name site. South African Archaeological Bulletin 50:110-120.

Delagnes, A., L. Wadley, P. Villa and M. Lombard 2006. Crystal quartz backed tools from the Howiesons Poort at Sibudu Cave. Southern African Humanities 18(1):43-56.

d'Errico, F. 2003. The invisible frontier: a multiple species model for the origin of behavioural modernity. Evolutionary Anthropology 12:188-202.

d'Errico, F., C.S. Henshilwood, G. Lawson, M. Vanhaeren, A-M. Tillier, M. Soressi, F. Bresson, B. Maureille, A. Nowell, J. Lakarra, L. Backwell and M. Julien 2003. Archaeological evidence for the emergence of language, symbolism, and music - an alternative multidisciplinary perspective. Journal of World Prehistory 17:1-70.

Gibson, N. E., L. Wadley and B.S. Williamson 2004. Residue analysis of backed tools from the 60000 to 68000 year-old Howiesons Poort layers of Rose Cottage Cave, South Africa. Southern African Humanities 16:1-11.

Goodwin, A.J.H. 1945. Some historical Bushman arrows. South African Journal of Science 41:429-443.

Henshilwood, C.S. and F. d'Errico 2005. Being modern in the Middle Stone Age: individuals and innovation. In C. Gamble and M. Porr (eds) The Hominid Individual in Context: Archaeological Investigations of Lower and Middle Palaeolithic Landscapes, Locales and Artefacts, pp. 244-264. London: Routledge.

Henshilwood, C.S., F. d'Errico, C.W. Marean, R.G. Milo and R. Yates 2001a. An early bone tool industry from the Middle Stone Age at Blombos Cave, South Africa: implications for the origins of modern human behaviour, symbolism and language. Journal of Human Evolution 41:631-678.

Henshilwood, C.S., J.C. Sealy, R.J. Yates, K. Cruz-Uribe, P. Goldberg, F.E. Grine, R.G. Klein, C. Poggenpoel, K.L. van Niekerk and I. Watts 2001b. Blombos Cave, southern Cape: preliminary report on the 1992-1999 excavations of the Middle Stone Age levels. Journal of Archaeological Science 28:421-448.

Henshilwood, C.S., F. d'Errico, R. Yates, Z. Jacobs, C. Tribolo, G.A.T. Duller, N. Mercier, J.C. Sealy, H. Valladas, I. Watts and A.G. Wintle 2002. Emergence of modern human behaviour: Middle Stone Age engravings from South Africa. Science 295:1278-1280.

Henshilwood, C.S., F. d'Errico, M. Vanhaeren, K. van Niekerk and Z. Jacobs 2004. Middle Stone Age shell beads from South Africa. Science 304:404.

Henshilwood, C.S. and C.W. Marean 2003. The origin of modern human behaviour: critique of the models and their test implications. Current Anthropology 44:627-651.

Henshilwood, C.S. and C.W. Marean 2006. Remodelling the origins of modern human behaviour. In H. Soodyall (ed.) The Prehistory of Africa: Tracing the Lineage of Modern Man, pp. 31-48. Johannesburg: Jonathan Ball Publishers.

Hodgkiss, T. 2006. In the mix: replication studies to test the effectiveness of ochre in adhesives for hafting. Unpublished MSc Dissertation. Johannesburg: School of Geography, Archaeology and Environmental Sciences, University of the Witwatersrand. 
Hovers, E., S. Ilani, O. Bar-Yosef and B. Vandermeersch 2003. An early use of colour symbolism: ochre use by modern humans in Qafzeh Cave. Current Anthropology 44:491-522.

Jacobs, Z., L. Wadley, A.G. Wintle and G.A.T. Duller submitted. New ages for the postHowiesons Poort, late and final Middle Stone Age at Sibudu Cave, South Africa. Journal of Archaeological Science.

Klein, R.G. 2000. Archaeology and the evolution of human behaviour. Evolutionary Anthropology 9:17-36.

Kuhn, S.L. and E. Hovers 2006. General Introduction. In E. Hovers and S.L. Kuhn(eds) Transitions Before the Transition: Evolution and Stability in the Middle Palaeolithic and Middle Stone Age, pp. 1-11. New York: Springer.

Lombard, M. 2004. Distribution patterns of organic residues on Middle Stone Age points from Sibudu Cave, KwaZulu-Natal, South Africa. South African Archaeological Bulletin 59:37-44.

Lombard, M. 2005. Evidence for hunting and hafting during the Middle Stone Age at Sibudu Cave, KwaZulu-Natal, South Africa: a multianalytical approach. Journal of Human Evolution 48:279-300.

Lombard, M. 2006a. Direct evidence for the use of ochre in the hafting technology of Middle Stone Age tools from Sibudu Cave, KwaZulu-Natal. Southern African Humanities 18(1):57-67.

Lombard, M. 2006b. First impressions on the functions and hafting technology of Still Bay pointed artefacts from Sibudu Cave. Southern African Humanities 18(1):27-41.

Lombard, M. 2007a. Archaeological use-trace analyses of stone tools from South Africa. Unpublished PhD Thesis. Johannesburg: School of Geography, Archaeology and Environmental Sciences, University of the Witwatersrand.

Lombard, M. 2007b. The gripping nature of ochre: the association of ochre with Howiesons Poort adhesives and Later Stone Age mastics from South Africa. Journal of Human Evolution 53:406-419.

Lombard, M. in press. Finding resolution for the Howiesons Poort through the microscope: microresidue analysis of segments from Sibudu Cave, South Africa. Journal of Archaeological Science (2007) doi:10.1016/j.jas.2007.02.021.

Lombard, M., I. Parsons and M.M. Van der Ryst 2004. Middle Stone Age lithic point experimentation for macro-fracture and residue analyses: the first set of experiments and preliminary results with reference to Sibudu Cave points. South African Journal of Science 100:159-166.

Lombard, M. and L. Wadley 2007a. The morphological identification of micro-residues on stone tools using light microscopy: progress and difficulties based on blind tests. Journal of Archaeological Science 34:155-165.

Lombard, M. and L. Wadley 2007b. Micro-residues on stone tools: the bigger picture from a South African Middle Stone Age perspective. In H. Barnard and J.W. Eerkens (eds) Theory and practice of archaeological residue analysis, pp. 18-28. BAR International Series 1650: Oxford.

Marean, C.W. and Z. Assefa 1999. Zooarcheological evidence for the faunal exploitation behavior of Neandertals and Early Modern Humans. Evolutionary Anthropology 8:22-37. 
Marean, C.W. and Z. Assefa 2005. The Middle and Upper Pleistocene African record for the biological and behavioural origins of modern humans. In A.B. Stahl (ed.) African Archaeology: a Critical Introduction, pp. 93-129. Oxford: Blackwell Publishing.

McBrearty, S. and A.S. Brooks 2000. The revolution that wasn't: a new interpretation of the origin of modern human behaviour. Journal of Human Evolution 39:453-563.

Mellars, P. 1973. The character of the middle-upper Palaeolithic transition in south-west France. In C. Renfrew (ed.) The Explanation of Cultural Change, pp. 255-276. London; Duckworth.

Mellars, P. 1995. Symbolism, language and the Neanderthal mind. In P. Mellars and K.R. Gibson (eds) Modelling the Human Mind, pp. 15-32. Cambridge: Macdonald Institute for Archaeological Research.

Mellars, P. 2005. The impossible coincidence: a single-species model for the origins of modern human behaviour in Europe. Evolutionary Anthropology 14:12-27.

Mellars, P. 2006. Why did modern populations disperse from Africa ca. 60,000 years ago? A new model. Proceedings of the National Academy of Science 103:9381-9386.

Minichillo, T.J. 2005. Middle Stone Age lithic study, South Africa: an examination of modern human origins. Ph.D Thesis: University of Washington.

Pargeter, J. 2007. To tip or not to tip: a multi-analytical approach to the hafting and use of Howiesons Poort segments. Unpublished Honours Dissertation. Johannesburg: School of Geography, Archaeology and Environmental Studies, University of the Witwatersrand.

Phillipson, D.W. 1976. The prehistory of eastern Zambia. Memoir Number Six of the British Institute in Eastern Africa, Nairobi.

Pienaar, M. 2006. Dating the Stone Age at Rose Cottage Cave, South Africa. Unpublished M.A. Dissertation. Pretoria: Department of Anthropology and Archaeology, University of Pretoria.

Plug, I. 2004. Resource exploitation: animal use during the Middle Stone Age at Sibudu Cave, KwaZulu-Natal. South African Journal of Science 100:151-158.

Rots, V. and P. van Peer. 2006. Early evidence of complexity in lithic economy: core-axe production, hafting and use at Late Middle Pleistocene site 8-B-11, Sai Island (Sudan). Journal of Archaeological Science 31:1287-1299.

Rots, V. and B.S. Williamson 2004. Microwear and residue analysis in perspective: the contribution of ethnographical evidence. Journal of Archaeological Science 31:1287-1299.

Shea, J.J. 2003. Close encounters: Neanderthals and modern humans in the Middle Palaeolithic Levant. The Review of Archaeology 24:42-56.

Shea, J.J. 2006. The origins of lithic projectile point technology: evidence from Africa, the Levant, and Europe. Journal of Archaeological Science 33:823-846.

Soriano, S., P. Villa and L. Wadley 2007. Blade technology and tool forms in the Middle Stone Age of South Africa: the Howiesons Poort and post-Howiesons Poort at Rose Cottage Cave. Journal of Archaeological Science 34:681-703.

Valladas, H., L. Wadley, M. Mercier, C. Tribolo, J.L. Reyss and J.L. Joron 2005. Thermoluminescence dating on burnt lithics from Middle Stone Age layers at Rose Cottage Cave. South African Journal of Science 101:169-174. 
Villa, P. and M. Lenoir 2006. Hunting weapons of the Middle Stone Age and the Middle Palaeolithic: spear points from Sibudu, Rose Cottage and Bouheben. Southern African Humanities 18(1):89-122.

Villa, P. and M. Lenoir in press. Hunting and hunting weapons of the Lower and Middle Paleolithic of Europe. In M. Richards and J.J. Hublin (eds) The Evolution of Hominid Diet. Springer, Leipzig.

Villa, P., A. Delagnes and L. Wadley 2005. A late Middle Stone Age artefact assemblage from Sibudu (KwaZulu-Natal): comparisons with the Middle Palaeolithic. Journal of Archaeological Science 32:399-422.

Wadley, L. 2001. What is cultural modernity? A general view and a South African perspective from Rose Cottage Cave. Cambridge Archaeological Journal 11:201-221.

Wadley, L. 2005a. Putting ochre to the test: replication studies of adhesives that may have been used for hafting tools in the Middle Stone Age. Journal of Human Evolution 49:587601 .

Wadley, L. 2005b. Ochre crayons or waste products? Replications compared with MSA 'crayons' from Sibudu Cave, South Africa. Before Farming 2005/3:1-12.

Wadley, L. 2005c. A typological study of the final Middle Stone Age tools from Sibudu Cave, KwaZulu-Natal. South African Archaeological Bulletin 60:51-63.

Wadley, L. 2006a. Revisiting cultural modernity and the role of ochre in the Middle Stone Age. In H. Soodyall (ed.) The Prehistory of Africa: Tracing the Lineage of Modern Man, pp. 49-63. Johannesburg: Jonathan Ball Publishers.

Wadley, L. 2006b. Partners in grime: results of multi-disciplinary archaeology at Sibudu Cave. Southern African Humanities 18(1):315-341.

Wadley, L. 2007. Announcing a Still Bay Industry at Sibudu Cave. Journal of Human Evolution 52:681-689.

Wadley, L. and Z. Jacobs 2006. Sibudu Cave: background to the excavations, stratigraphy and dating. Southern African Humanities 18(1):1-26.

Wadley, L. and M. Lombard 2007. Small things in perspective: the contribution of our blind tests to micro-residue studies on archaeological stone tools. Journal of Archaeological Science 34:1001-1010.

Wadley, L., M. Lombard and B.S. Williamson 2004. The first residue analysis blind tests: results and lessons learnt. Journal of Archaeological Science 31:1491-1450.

Wadley, L., B.S. Williamson and M. Lombard 2004. Ochre in hafting in Middle Stone Age southern Africa: a practical role. Antiquity 78:661-675.

Watts, I. 1998. The origin of symbolic culture: the Middle Stone Age of Southern Africa and Khoisan ethnography. Unpublished PhD Thesis. London: College University of London.

Watts, I. 2002. Ochre in the Middle Stone Age of southern Africa: ritualised display or hide preservative? South African Archaeological Bulletin 31:5-11.

Wells, C.R. 2006. A sample integrity analysis of faunal remains from the RSp layer at Sibudu Cave, Southern African Humanities 18(1):315-341.

Williamson, B.S. 1996. Preliminary stone tool residue analysis from Rose Cottage Cave. Southern African Field Archaeology 5:36-44. 
Williamson, B.S. 1997. Down the microscope and beyond: microscopy and molecular studies of stone tool residues and bone implements from Rose Cottage Cave. South African Journal of Science 93:458-464.

Williamson, B.S. 2000a. Prehistoric stone tool residue analysis from Rose Cottage Cave and other southern African sites. Unpublished Ph.D. Thesis. Johannesburg: School of Geography, Archaeology and Environmental Studies, University of the Witwatersrand.

Williamson, B.S. 2000b. Direct testing of rock painting pigments for traces of haemoglobin at Rose Cottage Cave, South Africa. Journal of Archaeological Science 27:755-762.

Williamson, B.S. 2004. Middle Stone Age tool function from residue analysis at Sibudu Cave. South African Journal of Science 100:174-178.

Williamson, B.S. 2005. Subsistence strategies in the Middle Stone Age at Sibudu Cave: the microscopic evidence from stone tool residues. In F. d'Errico and L. Backwell (eds) From Tools to Symbols: From Early Hominids to Modern Humans, pp. 513-524. Johannesburg: University of the Witwatersrand Press.

Wreschner, E.E. 1980. Red ochre and human evolution: a case for discussion. Current Anthropology 21:631-644.

Wreschner, E.E. 1982. Red ochre, the transition between Lower and Middle Palaeolithic and the origin of modern man. In A. Ronen (ed.) The Transition From Lower to Middle Palaeolithic and the Origin of Modern Man, pp. 35-39. BAR International Series 151: University of Haifa.

Wurz, S. 1999. The Howiesons Poort backed artefacts from Klasies River: an argument for symbolic behaviour. South African Archaeological Bulletin 54:38-50.

Wurz, S. and M. Lombard in press. 70 000-year-old geometric backed tools from the Howiesons Poort at Klasies River, South Africa: were they used for hunting? In K. Seetah and B. Gravina (eds) Bones for Tools, Tools for Bones: the Interrelationship of Lithic and Bone Raw Materials. McDonald Institute for Archaeological Research monographs. 